\title{
Assessment of Secondary School Teachers' Professional Development in the Use of Information Communication Technology for Teaching Mathematics in Ejigbo, Nigeria
}

\author{
Medinat Folorunso Salman $\mathrm{Phd}^{1}$, Oyeronke Olufunmilola Ogunlade $\mathrm{Phd}^{2}$, \\ Amos Akindele Ogunlade $\mathrm{Phd}^{3}$, and Olushina Aderemi Adegbami ${ }^{4}$ \\ ${ }^{I}$ Department of Science Education, University of Ilorin, Ilorin, Nigeria \\ ${ }^{2}$ Department of Science Education, University of Ilorin, Ilorin, Nigeria \\ ${ }^{3}$ College of the Immaculate Conception, Enugu \\ ${ }^{4}$ Department of Arts and Social Sciences Education, University of Ilorin, Ilorin, Nigeria
}

\begin{abstract}
The study sought information on teacher professional development in the use of Information Communication Technology in teaching Mathematics. The population comprised secondary school teachers and $r$ students in the study area. The sample consisted eight (8) secondary schools (three private and five public schools) using random sampling technique. Ten (10) teachers were purposively sampled from each school, which made up 80 Mathematics teachers while 122 students were randomly selected. The data collected were analyzed using frequency count, percentage and $t$-test statistics. The results revealed amongst others, that there was awareness among teachers and students on the use of Information Communication Technology (ICT) in teaching Mathematics at the secondary schools. There was no significant difference between the students mathematics achievement in both private and public secondary schools. Based on the findings, it was recommended that mathematics laboratory should be provided in the secondary schools to enable teachers and students improvise instructional materials that may not be readily available.
\end{abstract}

Keywords: Profession, Teacher professional development, Ejigbo, Nigeria, Teacher Education, Information Communication Technology (ICT).

\section{Introduction}

It is not an overstatement to say that mathematics is an indispensable tool in the march towards technological breakthrough. Mathematics cuts across all the fields of human endeavours in its wide application and mind development. However, despite its wide applicability, many students still could not find their feet in the subject. Governments and educational systems around the world recognize the need for students to be skilled, creative and confident users of a wide range of Information Communication Technology (Charalambous \& Karagiorgi, 2002), of which the knowledge of Mathematics is required. To acquire the appropriate knowledge and skills required by students, teachers' professional development, have significant roles to play in the authentic application and sustenance of ICT in schools. It is imperative therefore, that due consideration be given to the nature of programmes, pre-service teachers are exposed to in their teacher education courses. The importance of ICT in national development cannot be underestimated. The ICT are electronic devices and techniques used in collecting, storing, retrieving, processing, presenting and transmitting data (Oxford Mathematics Dictionary, P.56). Similarly, the ENCARTA world English dictionary (2009) described ICT as the use of technologies such as computers, electronics and telecommunication processes that distribute information in digital and other forms. Also, Thorpe, (2010) referred to ICT as the use of digital media and the internet. In the same vain, Ogunlade (2008), submitted that, the adoption of ICT in education would arouse a new interest among students, educators and educationists and possibly influence, if not change the attitude of teachers and students to learning. ICT in education would also promote global interaction and sustainable development.

The greatest challenge confronting the contemporary Nigeria society is the rapidly changing technology which requires adequate knowledge of mathematics. This is because without mathematics there is no science, without science there is no modern technology and without modern technology there is no modern society. (Ale \& Adetula, 2009). Maduakolam and Bell (2003) revealed that the problem militating against the use of existing and emerging technologies by pre-service and servicing teachers is the inability of the training institutions to integrate the required knowledge and skills into instruction and across curricula. This justifies the reason for adequate training of teachers on the use of ICT-based instructional strategy because it is one of the new teaching approaches that have been proven to be effective in the area of learners' active interaction with the 
learning material. Thijs, (2002) identified the benefits of ICT-based instructional strategy against the traditional method among others as: (i) a medium that provides learners the opportunity to work with people from different cultures, thereby helping to enhance learning and communication skills as well as their global awareness. (ii) Encourages interaction and cooperation among students, teachers, and experts regardless of where they are. Also, Greece, (2010) affirmed that ICT-based instruction promotes student-centered learning. It was further explained that it focuses on students' needs, abilities, interests, and learning styles with the teacher as facilitator of learning.

In Nigeria, more have to be done in the area of professional development in the use of ICT among secondary school teachers. Teachers have not been given expected opportunities, only few of them have been going through self development in ICT, some of them that cannot afford the exorbitant cost of training, have indirectly resulted to fate which should not be. The quality or value of teachers could be determined by their abilities to cope with innovations in teaching and learning. It is therefore imperative to occasionally ensure teachers' personal development and career advancement both in their subject disciplines and in teaching profession. This informed the assessment carried out by the present study on professional development of teachers in Ejigbo in their use of ICT in teaching Mathematics.

\section{The Problem}

The rapidly changing technology has implication for teaching and learning since education is the only channel through which the beneficiaries can get awareness. The knowledge of mathematics is required by all users of technologies and that is why it is one of the core subjects at the primary and secondary school levels of Nigeria education system. In spite its importance, the annual chief examiners' reports on students' achievement in mathematics had not been favourable. Table 1 shows the trend of achievements for six consecutive years.

Table 1: Trend of students' achievement in West African School Certificate Examinations from 20052010.

\begin{tabular}{|c|c|c|c|c|c|}
\hline $\begin{array}{l}\text { Year of } \\
\text { Entry }\end{array}$ & $\begin{array}{l}\text { Total } \\
\text { Entry }\end{array}$ & Total Sat & $\begin{array}{l}\text { Pass at Credit } \\
\text { level }\end{array}$ & Ordinary Pass & Failed \\
\hline 2005 & 1080133 & $\begin{array}{l}105453 \\
9711 \%\end{array}$ & $\begin{array}{l}402982 \\
3820 \%\end{array}$ & $\begin{array}{l}267600 \\
2535 \%\end{array}$ & $\begin{array}{l}363055 \\
34.41 \%\end{array}$ \\
\hline 2006 & 1170137 & $\begin{array}{l}1249028 \\
98.33 \%\end{array}$ & $\begin{array}{l}584024 \\
46.75 \%\end{array}$ & $\begin{array}{l}357325 \\
31.09 \%\end{array}$ & $\begin{array}{l}286826 \\
24.95 \%\end{array}$ \\
\hline 2007 & 1270136 & $\begin{array}{l}1249028 \\
98.33 \%\end{array}$ & $\begin{array}{l}584024 \\
46.75 \%\end{array}$ & $\begin{array}{l}333844 \\
26.72 \%\end{array}$ & $\begin{array}{l}302774 \\
24.95 \%\end{array}$ \\
\hline 2008 & 1292890 & $\begin{array}{l}1268213 \\
98.09 \%\end{array}$ & $\begin{array}{l}726398 \\
57.27 \%\end{array}$ & $\begin{array}{l}302266 \\
23.83 \%\end{array}$ & $\begin{array}{l}218618 \\
17.23 \%\end{array}$ \\
\hline 2009 & 1373009 & $\begin{array}{l}1348528 \\
98.22 \%\end{array}$ & $\begin{array}{l}634382 \\
47.09 \%\end{array}$ & $\begin{array}{l}344635 \\
25.56 \%\end{array}$ & $\begin{array}{l}3369511 \\
23.79 \%\end{array}$ \\
\hline 2010 & 1351551 & $\begin{array}{l}1351557 \\
99.94 \% \\
\end{array}$ & $\begin{array}{l}534841 \\
39.51 \% \\
\end{array}$ & $\begin{array}{l}677007 \\
50.09 \% \\
\end{array}$ & $\begin{array}{l}139709 \\
10.34 \% \\
\end{array}$ \\
\hline
\end{tabular}

Table 1 show that less than $50 \%$ of the examinees made a credit pass in mathematics and are qualified for admission into the university or other tertiary institutions. The only remarkable year with $50 \%$ credit pass was 2008 which is still worrisome when compared with the previous and subsequent years. The question is that; what happens to the remaining larger percentage? 


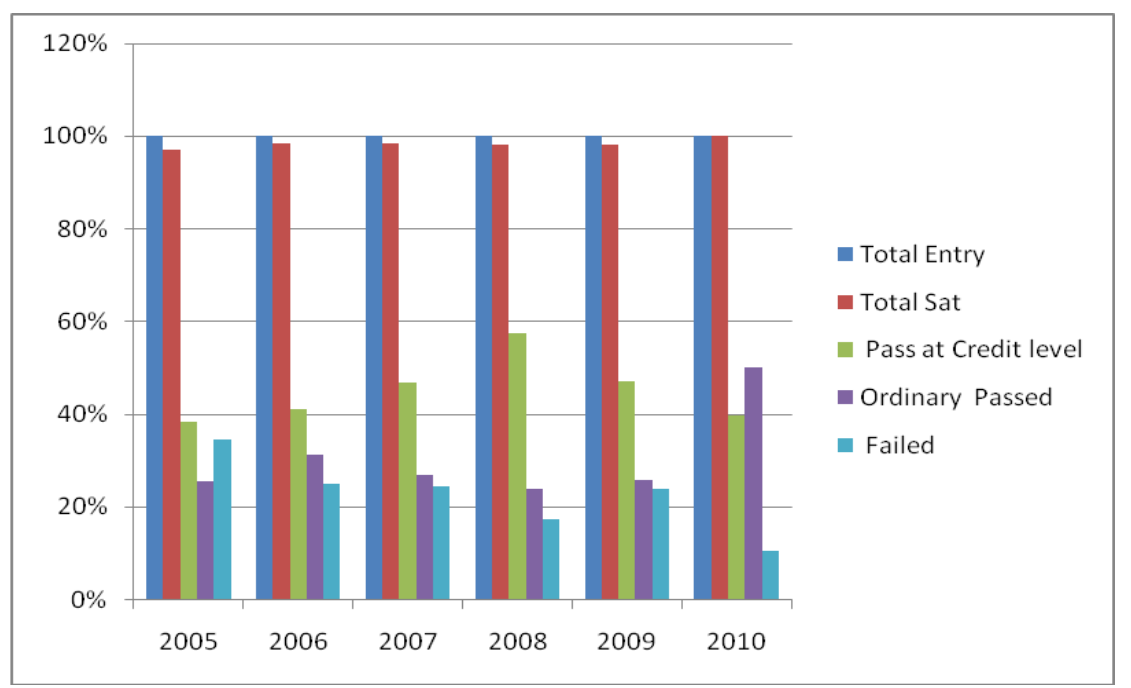

Figure 1: Graphical representation of students' achievements in West African School Certificate Examinations from 2005-2010

Figure 1 show the bar graph of the $\%$ that registered, the $\%$ that sat for the examinations, the $\%$ that passed at credit level, those with ordinary pass and failure in each year respectively over a period of six years (2005-2010). The bar chart also indicated the highest percentage of students that passed at credit level in the year 2008. Research reports have identified teachers' methods of delivery as one of the major responsible factors for inadequate performances in the subject. The traditional didactic method is no longer adequate to meet the demands of mathematics education (Salman, 2010). Replacing the traditional mode of instruction with the use of computer and the internet source provider would widen students' access to topics and scope to learning (Wikipedia, 2010). It is the recognition for the use of electronic devices for teaching and learning of mathematics to enhance performance and cope with the technological advancement that led to the introduction of computer education in to the secondary school Mathematics curriculum. Chong, Horani and Daniel (2005) reported that after the Malaysian Ministry of Education had implemented the use of Laptops in the teaching of Mathematics and science since 2003, it was observed that teachers are not fully utilizing these facilities in their teaching. This may be due to the ministry's failure to ascertain the teachers' professional development in the use of laptops.

In the same vein, three states (Kwara, Kano and Kaduna) in Nigeria embarked on three (3) years project from 2007 to 2011 on Professional Development of which Teacher Professional Development (TPD) is a component. The main purpose of the Teacher Professional Development was to improve teaching and learning in schools by encouraging teachers to adopt "Learner-centered" approaches in their classrooms. Series of workshops were organized for the following people: supervisors and inspectors; head teachers and principals; and finally classroom teachers drawn from the basic level of Nigeria Education System. There were face-to-face workshops, school visits and cluster workshops on teaching of English (First Year), Mathematics and science $\left(2^{\text {nd }}\right.$ year) and social studies ( $3^{\text {rd }}$ year). The use of ICT was not emphasized in the subjects' modules; include Mathematics in the professional development but how learners can be actively involved in class activities. In the same vein, secondary school teachers in Ejigbo, between 2004 and 2007 took part in workshops on professional development, specifically on ICT. Though only few of the teachers took part in the workshops. The present study therefore, sought information on whether or not the professional development opportunity on the use of ICT for instruction enjoyed by secondary school teachers in Ejigbo, Nigeria, had impact on the performance of their students in Mathematics.

\section{Study Purpose}

The major thrust of this study was to assess secondary school teachers' professional development in the use of information communication technology Mathematics in Ejigbo, Nigeria. Specifically the study focused on the following:

1. Awareness of secondary school teachers' professional development in the use of ICT for teaching Mathematics.

Professional development skills of teachers in the use of ICT for teaching Mathematics

2. Teachers use of ICT in public and Private Secondary Schools 
3. Compare students' achievement with Teachers' professional development skills in the use of ICT for teaching Mathematics.

\section{Research Questions}

Based on the purpose of the study, the following questions are raised

1. Are secondary school teachers in Ejigbo aware of the use of ICT in teaching Mathematics?

2. What is the assessment of secondary school teachers' professional development skills in the use of ICT for teaching Mathematics?

3. Is there any difference in teachers use of ICT in public and Private Secondary Schools

4. Does teachers' professional development in the use of ICT for teaching mathematics have impact on students' achievement in Mathematics in private and public secondary schools?

\section{Hypotheses}

Research questions 3 and 4 are now Hypotheses one and two.

Ho$_{1}$ : There is no significant difference in teachers' use of ICT for Mathematics teaching in secondary schools in Ejigbo.

Ho2: There is no significant difference in achievement of students taught with the use of ICT for teaching Mathematics in private and public secondary schools in Ejigbo

\section{Literature Review}

It has been observed that every field of science and technology has substantial mathematics content though of different degree. Okereke (2006) described the functional role of mathematics to science and technology as multifaceted and multifarious that no area of science, technology and business enterprise can escape its application. Okigbo and Osuafor (2008) attributed the poor performances to the fact that the most desired technological, scientific and business application if it cannot be sustained. Also Marwaha (2009) identified teaching mathematics as an abstraction, removing it from application, treating it as a subject not relevant in other school subjects, placing much emphasis on symbol and manipulation with little attention to problem solving, as reasons why students do not fair well in mathematics. In the same vein, Srinsvasa (1978) and Ogunkunle (2000) identified non-use of laboratory approach which is practical oriented and also involve the use of computer and the internet (ICT) as major factors that contribute to poor achievement in mathematics particularly by secondary school students. The integration of ICT to the teaching of Mathematics is a great challenge to secondary school teachers in Nigeria because the teacher training institutions that are supposed to be driving force towards the implementation of ICT in teaching school subjects are not adequately professionally empowered in effective utilization of ICT.

\subsection{Research Type}

\section{Methodology}

The study was a descriptive survey which involved administration of questionnaire to the respondents and assessment of students' performance in Mathematics. It involves prepared questionnaire and performance test which were used to collect data.

\subsection{Sample and Sampling Techniques}

The population of the study comprised all the secondary school Mathematics teachers and their students in Ejigbo Local Government area of Osun State, Nigeria. Eight (8) secondary schools were selected as sample through simple random sampling technique. Eighty (80) teachers and One hundred and twenty two (122) students were chosen from the sampled schools through purposive sampling technique. Table 2a shows the selection of teachers based on qualification and subject specialization.

Table 2a: Frequency count of respondents according to qualification and subject specialization

\begin{tabular}{llll}
\hline & \multicolumn{2}{l}{ Subject Specialization } & \\
Qualification & Mathematics & Others & Total \\
\hline N.C.E & 10 & 15 & 25 \\
B.Sc., Graduate/ H.N.D & 20 & 25 & 45 \\
M.Sc./M.Ed. & - & 10 & 10 \\
Total no Selected & 30 & 50 & 80 \\
\hline
\end{tabular}


Table 2b: $\quad$ Frequency count of selected schools

\begin{tabular}{ll}
\hline School Type & Number \\
\hline Private & 52 \\
Public & 70 \\
Total & 122 \\
\hline
\end{tabular}

It is indicated in table 2a that out of the eighty teachers purposively selected; only 30 were specialized in Mathematics while the remaining 50 were not experts in Mathematics but were asked to teach the subject. This has strong implication for students' performance in the subject.

\subsection{Instrument}

Researchers-designed questionnaire and a performance test were used as the main instruments for the study. Oral interview and checking of relevant materials in the schools also provided additional information. The instruments were designed to assess the awareness of ICT, availability of ICT materials for mathematics teaching and learning and utilization of ICT in teaching mathematics. Each questionnaire was divided into 3 sections. The first section sought information on students' and teachers' personal data, section 2 consisted Yes/No responses from teachers and student for teacher use of ICT to teach mathematics. The last session contained open ended questions for teachers and students separately to check for awareness of ICT for teaching mathematics and professional development. The performance test was administered on the students.

\subsection{Validation}

The questionnaire was given to educators, experts in mathematics education and educational technologists, research methods specialists for comments and guidance. The questionnaire forms were given to experts also for validity, 20 questionnaire copies were administered in some schools outside the sample to test for reliability. The reliability was thus tested through test re-test method using spearman rank correlation. The correlation value of 0.98 was obtained.

\subsection{Administration}

The researchers administered the questionnaire in the 8 selected schools (Private and Public). The administration of the questionnaire was done by the researchers to ensure prompt response and high rate of outcome. All the 80 copies of the questionnaire given to mathematics teachers were filled and returned to the researchers. Also the 122 copies of the tests administered to students were also returned.

\section{Data Analysis And Results}

The data obtained from the questionnaire was analyzed using frequency count and percentage, while ttest analysis was used to test the null hypotheses generated.

\subsection{Results}

8.1.1 Research Question One: Are secondary school teachers in Ejigbo aware of use of ICT in teaching Mathematics.

Table 3 Teachers awareness of ICT

Table 3: Frequency counts and percentages on teachers' awareness of ICT

\begin{tabular}{llllll}
\hline Items & Statement & $\begin{array}{l}\text { No of Yes } \\
\text { Responses }\end{array}$ & $\begin{array}{l}\text { \% } \\
\text { Responses }\end{array}$ & $\begin{array}{l}\text { No } \\
\text { Responses }\end{array}$ & $\begin{array}{l}\text { \% of No } \\
\text { Responses }\end{array}$ \\
\hline 1 & $\begin{array}{l}\text { I have been aware of ICT } \\
\text { I have no knowledge of }\end{array}$ & 50 & 62.5 & 30 & 37.5 \\
3 & $\begin{array}{l}\text { ICT } \\
\text { I am not aware that ICT } \\
\text { is an instructional } \\
\text { strategy for teaching } \\
\text { Mathematics }\end{array}$ & 45 & 43.75 & 45 & 56.25 \\
& $\begin{array}{l}\text { I am aware that computer } \\
\text { is a component of ICT }\end{array}$ & 50 & 62.50 & 30 & 37.50 \\
\hline $\begin{array}{l}\text { I have attended series of } \\
\text { seminars which increase } \\
\text { my knowledge of ICT }\end{array}$ & 10 & 12.50 & 70 & 87.50 \\
6 & $\begin{array}{l}\text { I am aware that palmtop } \\
\text { performs the same } \\
\text { function with desktop. }\end{array}$ & 10 & 12.5 & 70 & 87.50 \\
\hline
\end{tabular}


On Mathematics teachers awareness of ICT $62.50 \%$ of the teachers claimed that they have been aware while $37.50 \%$ have not been aware. Also on the knowledge of ICT, 43.75 claimed to have the knowledge while $56.25 \%$ have not acquired the knowledge. Result also showed that $45 \%$ were aware that ICT is an instructional strategy for teaching Mathematics, 55\% were not aware of such fact.62.5 respondents claimed that they were aware that computer is a component of ICT while 37.5\% were not. Among the sampled teachers $12.50 \%$ of them had attended seminars which increased their knowledge of ICT, 87.5\% were on the negative. Moreover from the same table, majority $(87.50 \%)$ claimed that they were not aware that palmtop performs the same function with desktop, which implies that mathematics teachers' awareness would have to be worked on.

8.1.2 Research Question Two: What is the assessment of secondary school teachers' professional development in the use of ICT in teaching mathematics? This question was answered using frequency count and percentage. Table 4 shows the responses of Teachers on use of ICT in teaching Mathematics.

Table 4: Frequency counts and percentages on teachers' use of ICT and related Instructional materials

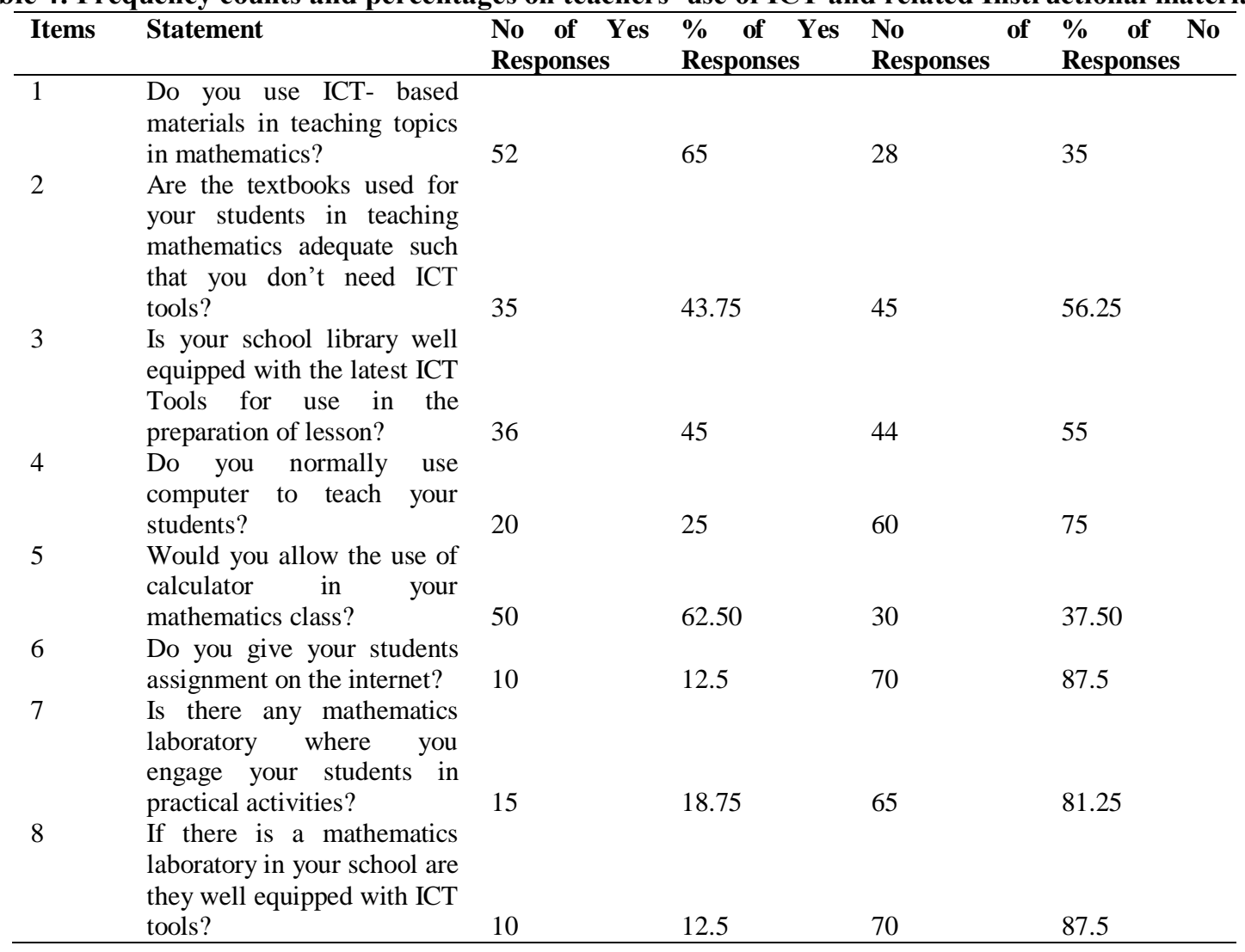

On the use of ICT related materials in the teaching of mathematics $65 \%$ of the teachers claimed that they were always using them. Also on the adequacy of the available textbooks used for mathematics teaching, the result showed that they were not adequate because $56.25 \%$ gave negative response. On item $3,55 \%$ of the respondents, claimed that schools in Ejigbo lacked well equipped library where they can lay their hands on relevant ICT tools. On the use computer for Mathematics teaching, 75\% of the respondents claimed that they have not been using such for teaching Mathematics. Also $62.50 \%$ indicated that there was nothing like use of calculator in their mathematics classes. On the use of internet, $87.5 \%$ indicated, that they were not giving their students assignment on the internet. In item 7, 81.25\% claimed that their schools had no mathematics laboratories. Finally, $87.50 \%$ of the sampled teachers indicate that the available laboratories were not well equipped with ICT tools. This implies that mathematics teachers would have to teach the students without relevant ICT tools in the schools.

\subsection{Hypotheses Testing}

8.2.1 Ho: There is no significant difference between the teachers' use of ICT in both public and private secondary school. This hypothesis is equivalent to research question 3 . This was analyzed using t-test 
Table 5: t-test analysis on teachers' use of ICT for teaching Mathematics in Private and Public Secondary Schools. In Ejigbo

\begin{tabular}{lllllll}
\hline School & Mean & SD & $\mathbf{N}$ & $\mathbf{d f}$ & $\mathbf{t}_{\text {cal }}$ & $\mathbf{t}_{\text {tab }}$ \\
\hline Private & 62.55 & 9.77 & 40 & & & \\
& & & & 120 & 0.17 & 1.67 \\
Public & 62.18 & 10.27 & 40 & & & \\
\hline
\end{tabular}

The $\mathrm{t}$-calculated of 0.17 is less than the table value of 1.67. It means that there was a significant difference in teachers' use of ICT for teaching Mathematics in private and public secondary schools at 0.05 significant levels. Hence, the hypothesis was hereby rejected.

8.2.1 Ho2: There is no significant difference in performance scores of students taught Mathematics with the use of ICT in private and public secondary schools in Ejigbo

This hypothesis is also equivalent to research question 4 .This was tested using t-test statistic.

Table 6: t-test analysis on the impact of ICT on students' achievement in Mathematics

\begin{tabular}{lllllll}
\hline School & Mean & SD & $\mathbf{N}$ & $\mathbf{d f}$ & $\mathbf{t}_{\text {cal }}$ & $\mathbf{t}_{\text {tab }}$ \\
\hline Private & 19.13 & 7.94 & 52 & 120 & 8.34 & 1.98 \\
Public & 17.79 & 7.37 & 70 & & \\
\hline
\end{tabular}

Table 6 shows t-test analysis on secondary school students' mathematics achievement scores. The null hypothesis $\left(\mathrm{Ho}_{3}\right)$ postulated that there is no significant difference in students' mathematics achievement scores in private and public secondary schools. It is indicated in the table that the calculated value of 8.34 is greater than the critical or table value of 1.98. In other words there no was significant difference in the achievement scores of students in private and public secondary schools in Ejigbo at 0.05 alpha level of significance.

\section{Discussion Of Findings}

The findings from the study reveals that out of the 80 secondary school teachers that participated in the study, thirty (30) teachers specialized in mathematics while 50 teachers were in other areas of specialization but their school authorities allowed them to teach mathematics. In the selected schools, only $37.50 \%$ of the teachers indicated that there was mathematics laboratory in their schools which would have assisted the use of ICT. Also, a reasonable number affirmed that they have not been having opportunities of attending seminars and workshops on ICT which would have increased their awareness of ICT. An important observation made by the researchers in the scoring of students' answer scripts was the in ability to correctly interpret word problems into equivalent equations. This is consistent with the finding of Marwaha (2009) who reported that teachers place emphasis on numerical problems that involve the use of symbols and manipulations, with little attention to problem solving involving word expressions.

It was also revealed that the secondary school teachers under study were aware of ICT tools and its use for teaching mathematics but there was a significant difference in its use by teachers in private and public secondary schools. The teachers expressed their concern about the high cost of ICT tools which they are not capable of purchasing except the government can subsidize. In other word, teachers at the secondary school level are still lagging behind in modern technological modes of instruction. The significant difference in the use of ICT by teachers in private and public school could be attributed to efforts by private school to adequately equip their schools for purpose of patronage. The non significant difference in the achievement of the students implies that the use ICT for teaching Mathematics did not have impact on their achievement. For effective use of ICT for teaching and learning both the teachers and the learners must be cognitively and affectively prepared to embrace the innovations in teaching and learning particularly in the use of ICT for classroom instruction.

\section{Conclusion And Recommendations}

Effective integration of technology in the classroom stimulates students and teachers in attempting more complex tasks and materials. Mathematics teachers may want to use technology in this manner to develop higher expectations for their students ICT will equally enable students to engage in content areas, activities that are challenging and also collaborative, cooperative and interdisciplinary studies.

Based on the outcome of the research the following recommendations are considered relevant: As confirmed in the present study, the value for the use of ICT in schools in Nigeria is still limited to private and unity schools and few public secondary schools. For all schools irrespective of the type, to go on ICT-based instructional strategies, a lot of money would be required because it is capital intensive.

Awareness of its importance should be created for mathematics teachers in public secondary schools in particular and teachers in general through organized workshops. The effective use of ICT in teaching Mathematics at the secondary level requires human ware such as: Computer operators, programmers, analysts, 
engineers and trainers that would assist in training and retraining of mathematics teachers who will impart knowledge and skills to learners. The government should give necessary financial support required to get the required human ware and the necessary materials.

Pre-service and service mathematics teachers should be sent on intensive training course of one year or six months or three months on ICT knowledge and skills.

Mathematics laboratory should be provided in secondary schools to enable teachers and students improve on teaching and learning respectively particularly in the practical use of ICT tools.

Institutions responsible for curricula development and teachers' development should collaborate on the alignment of teacher development programmes and integration of the use of ICT in mathematics and science education.

Curriculum developers of programmes teacher education should develop instructional plans across board and the applications, to facilitate the integration of the use of ICT in teacher professional development in mathematics.

The relevant Government should be ready to provide ICT tools and ICT training for teachers so that mathematics teachers will be able to have positive influence on their students.

\section{References}

[1] Charalambous, K \& Karagiorgi, D (2002). Information and Communication Technology in-service Training for Teachers. Journal of Information Technology for Teacher Education 11(2). 319-334

[2] Oxford Dictionary of English (Second Edition) - Free software.

[3] Bloomsbury Microsoft 2009. Encarta world English dictionary (North American Edition). London: Bloomsbury publisher.

[4] Thorpe, M.(2010).The impact of ICT on lifelong Learning. Open learning, 2 (2) Education-

[5] Ogunlade O.O. (2008) ICT in Educational management and Development. Managing Education for sustainable development in Developing countries 291-294.

[6] Ale, S.O. \& Adetula, L.O. (2009). The impact of information and communication technology on Mathematical Science Education. The Journal of the Mathematical Association of Nigeria. 34(1), 1-6

[7] Maduakolam, I., \& Bell, E. (2003). A product-based faculty professional development model for infusing technology into teacher education. Contemporary Issues in Technology and Teacher Education [Online], 3(3). Retrieved October 11, 2005, from http://www.citejournal.org/vol3/iss3/currentpractice/article1.cfm

[8] Thijs, A. (2002). Learning through the web .Retrieved 15th January, 2011 from http://www.decidenet.n//publicatory/web Based Learning .Pdf

[9] Salman, M. F. (2010).Laboratory-based teaching in a Nigeria University. 1st International Conference of Education Faculties in West Africa (CEFWA) proceeding at university of Ilorin between 8th and 11th February 2010.

[10] Wikipedia,(2010).free online article Retrieved on 25 sept;2010,from http://www.educationwikipedia/education 2010.com.

[11] Chong Chee Keong, Sharaf Horani \& Jacob Daniel (2005). A Study on the Use of ICT in Mathematics Teaching, Malaysian Online Journal of Instructional Technology (MOJIT) Vol. 2, No. 3, pp 43-51December 2005 ISSN: 1823-1144

[12] Okereke, S. C (2006).Effects of prior knowledge of implication of mathematics task/concept to career types and gender on students achievement, interest and retention in U.Uzew (Ed) science Teachers' Association of Nigeria proceedings of the 47th Annual conference, $253-259$

[13] Okigbo,C.E \& Osuafor, M.A (2008). Effects of using Mathematics laboratory in teaching Mathematics students. Educational Research and Review, 3(8), 257-261

[14] Srinivasa, N. (1978). A laboratory for teaching mathematics. Journal of Science Teachers' Association of Nigeria 9 (1), 22 -24.

[15] Ogunkunle, R.A. (2000). Teaching of Mathematics in schools. The laboratory approach: the Nigeria Teacher today, 8 (1, 2), 180184. 